\title{
POMIAR EFEKTYWNOŚCI PRZEDSIĘBIORSTW SEKTORA E-COMMERCE - WYNIKI BADAŃ
}

DOI: $10.33141 /$ po.2020.07.04

Barbara Buraczyńska
Przegląd Organizacji, Nr 7(966), 2020, s. 28-34

www.przegladorganizacji.pl

(c) Towarzystwo Naukowe Organizacji i Kierownictwa (TNOiK)

\section{Wprowadzenie}

$\mathrm{E}$ fektywność przedsiębiorstwa jest pojęciem niejednoznacznym i różnorodnie definiowanym (Głodziński, 2015, s. 166-167; Ziębicki, 2014, s. 21). W literaturze polskiej i zagranicznej wymieniane są różne wskaźniki efektywności. Niektóre z nich mogą być wykorzystywane do oceny każdej organizacji, inne są specyficzne tylko dla danego rodzaju działalności, np. produkcyjnej. Istnieje też wiele wskaźników efektywności, a w szczególności wskaźników pozaekonomicznych, typowych dla firm handlowych z sektora e-commerce. Wartości wskaźników są kluczowe przy podejmowaniu decyzji operacyjnych i strategicznych. Ponadto efektywność jest też wskazywana jako jeden $\mathrm{z}$ czynników wpływających na funkcjonowanie przedsiębiorstwa, decydujących o jego przetrwaniu i determinujących jego rozwój (Osbert-Pociecha, 2007, s. 337).

Prowadzenie badań porównawczych przedsiębiorstw e-commerce może być oparte na analizie danych pozyskanych bezpośrednio $\mathrm{z}$ systemów teleinformatycznych firmy. Jednakże menedżerowie są niechętni do ich udostępniania. Tymczasem wyrażają oni zainteresowanie udziałem w badaniach kwestionariuszowych (szczególnie z wykorzystaniem narzędzi internetowych jak ankieta internetowa), w których na każdym etapie badania mogą decydować, czy udzielą odpowiedzi na konkretne pytanie (Kaden, 2008, s. 185-186). Do analizy efektywności działania przedsiebiorstwa należy wykorzystywać takie wskaźniki i mierniki, które z jednej strony da się pozyskać, z drugiej strony jednoznacznie oceniają działalność firmy, uwzględniając jej specyfikę. W badaniach kwestionariuszowych, w których menedżerowie nie mają bezpośredniego kontaktu $\mathrm{z}$ autorem ankiety $\mathrm{w}$ trakcie jej wypełniania, równie ważna jest prostota ich oszacowania przez respondentów. Nieodpowiednio dobrane mierniki efektywności w badaniach mogą skutkować odmową odpowiedzi na pytanie przez respondenta lub udzieleniem odpowiedzi nieadekwatnej do rzeczywistości. W konsekwencji wyniki badań nie odzwierciedlą stanu faktycznego.

Problemem badawczym jest pomiar efektywności przedsiębiorstw $\mathrm{z}$ branży e-commerce $\mathrm{z}$ wykorzystaniem badań kwestionariuszowych. Celem badań była ocena efektywności pracy przedsiębiorstw prowadzących sklepy internetowe w oparciu o grupę pozaekonomicznych wskaźników i mierników efektywności organizacji. Kryterium doboru wskaźników i mierników była łatwość ich pozyskania. Stąd też przedstawiono różne definicje efektywności i jej klasyfikację. Zaprezentowano wybrane wskaźniki i mierniki efektywności przedsiębiorstw e-commerce wraz z opisem sposobu ich pomiaru. Na podstawie przeglądu literatury zaproponowano kilka wskaźników i mierników mogących posłużyć do oceny efektywności, które równocześnie uwzględniają cele stawiane przez podmioty gospodarcze prowadzące sklepy internetowe oraz specyfikę badań kwestionariuszowych. Następnie oceniono ich użyteczność w kwestionariuszowych badaniach porównawczych przedsiębiorstw e-commerce. Przeprowadzone badania pokazały zarówno mocne, jak i słabe strony wskaźników i mierników wybranych do oceny efektywności firm prowadzących e-sklepy.

\section{Definicje efektywności i jej klasyfikacja}

E fektywność jest pojęciem bardzo szerokim, może być E ona rozumiana jako: wydajność, kompetencyjność, sprawność, funkcjonalność, komunikatywność, a nawet moralność (Holstein-Beck, 1997). Powiązana jest ona również z pojęciami: produktywność, rentowność, skuteczność oraz racjonalność (Skrzypek, 2012, s. 314). Słownik ekonomiczny przedsiębiorcy (2000) definiuje efektywność jako najlepsze rezultaty $\mathrm{w}$ produkcji, dystrybucji i usługach, uzyskane po najniższych kosztach.

$\mathrm{Na}$ efektywność organizacyjną (zwaną również efektywnością funkcjonowania systemu) składają się: efektywność gospodarowania (ekonomiczna) i efektywność pozaekonomiczna (rys. 1). Efektywność ekonomiczna to takie gospodarowanie zasobami, które prowadzi do osiągnięcia założonych wyników przy jak najniższych kosztach (ujęcie finansowe) albo maksymalizowania wyniku przy założonych nakładach (ujęcie produktywnościowe) (Szymańska, 2010, s. 156). Jest ona bardzo istotna, gdyż na niej koncentrują się badania rezultatów przeprowadzanych działań w przedsiębiorstwie (Jaki, 2011, s. 3-7).

Efektywność można podzielić ze względu na kryterium charakteru czynników ją kształtujących. Wówczas wyróżnia się efektywność techniczną i efektywność ekonomiczną (rys. 2). Na efektywność techniczną składają się efektywność technologii (stosunek wartości produkcji uzyskanej do zakładanej maksymalnej wartości produkcji) i techniczna efektywność skali (osiąganie wraz ze wzrostem produkcji wyższej relacji produkcji do nakładów). W efektywności ekonomicznej wyodrębnia się z kolei: efektywność alokacji (wyznaczana przez 
kombinację czynników produkcji i produktów), ekonomiczną efektywność skali (wyznaczana relacjami pozatechnicznymi) i efektywność cenową (niskie nakłady i wysokie ceny sprzedaży produktów) (Kowalski, 1992, s. 30).

E. Skawińska i R.I. Zalewski (2016, s. 17) wskazują na koegzystencję wielu celów w przedsiębiorstwie, a tym samym na zasadność wykorzystania również pozaekonomicznych wskaźników efektywności. Ocena efektywności przedsiębiorstwa powinna uwzględniać jego wartość, jego udział w rynku, a także zachowanie równowagi społecznej, wpływ na środowisko naturalne czy racjonalność wykorzystania zasobów.

Wśród wskaźników do pomiaru efektywności wyróżnia się: kluczowe wskaźniki efektywności (ang. Key Performance Indicators - KPI), które obrazują kluczowy czynnik modelu biznesu; wskaźniki efektywności (ang. Performance Indicators), które mają charakter wspomagający dla kluczowych czynników; kluczowe wskaźniki wyniku (ang. Key Results Indicators), które ogólnie opisują wynik danego zjawiska oraz wskaźniki wyniku (ang. Results Indicators), które opierają się na zewnętrznych krytycznych miarach sukcesu (Parmenter, 2015, s. 3-4).

Opisane wskaźniki efektywności nie zawsze mogą być wykorzystane $\mathrm{w}$ badaniach ze względu na ograniczoną możliwość ich pozyskania (dane wrażliwe firmy). Stąd też dobór wskaźników efektywności powinien uwzględniać nie tylko cele przedsiębiorstwa i specyfikę prowadzonej działalności, ale także dostępność danych dla badacza.

\section{Mierniki efektywności dla przedsiębiorstw prowadzących sprzedaż internetową}

D ziałalność handlowa prowadzona $\mathrm{z}$ wykorzystaniem sklepów internetowych charakteryzuje się gromadzeniem i przetwarzaniem ogromnych ilości danych.
Ponieważ mogą być one łatwo monitorowane przez aplikacje internetowe, stanowią one cenne i tanie źródło informacji o efektywności przedsiębiorstwa prowadzącego sprzedaż internetową. Z punktu widzenia wydajności organizacji istotny jest wybór tych wskaźników, które najlepiej odzwierciedlają wyniki firmy (Saniuk, Saniuk, 2017, s. 208-209).

Uwzględniając etapy procesu zakupów internetowych, A. Zagajewski i S. Saniuk (2018, s. 696-699) zaproponowali następujące kluczowe wskaźniki efektywności: wskaźnik odrzuceń (procent użytkowników opuszczających stronę bez dokonania jakichkolwiek działań), wskaźnik porzuconych koszyków (odnoszący się do liczby porzuconych koszyków), wskaźnik konwersji (odnoszący się do liczby osób, które wykonały określoną akcję - liczba konwersji przez liczbę wszystkich wygenerowanych sesji), wskaźnik zwrotów i reklamacji, wskaźnik powracających użytkowników. Jednocześnie wskazują oni czynniki, które świadczą o efektach prowadzonej działalności. Są to opinie klientów, pozycja w wynikach wyszukiwarki, obecność w porównywarkach cen, szybkość działania sklepu, przyjazność, responsywność (właściwe wyświetlanie się strony na różnych urządzeniach).

Eksperci e-commerce często na liście kluczowych wskaźników efektywności umieszczają też: życiową wartość klienta (ang. Customer Lifetime Value - CLV), średnią wartość zamówienia (ang. Average Order Value - AOV) czy stosunek liczby zamówień pochodzących z ruchu mobilnego do całkowitej liczby wizyt z urządzeń mobilnych. Średnia wartość zamówienia to wielkość osiągniętego przychodu w stosunku do liczby zamówień w ustalonym okresie, a średnia wartość klienta może być liczona jako iloczyn średniej wartości zamówienia, średniej liczby zamówień jednego klienta i średniego czasu życia klienta, tj. okresu, w którym składa on zamówienia (Zawadzki, 2018). Wśród kluczowych wskaźników

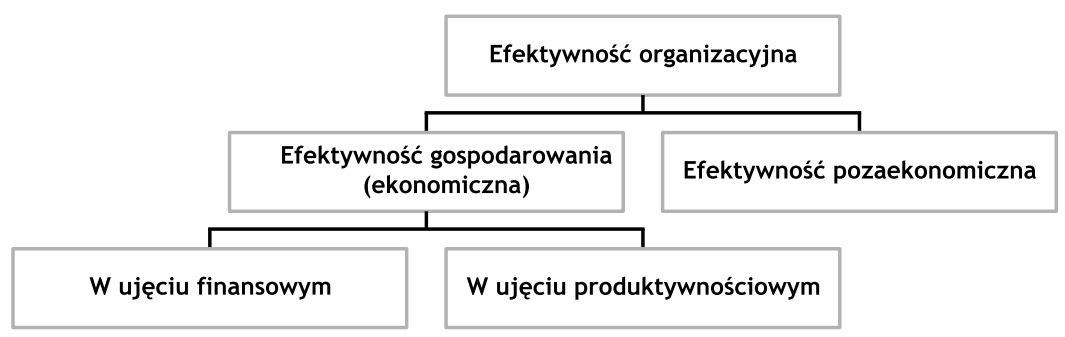

Rys. 1. Kategorie efektywności organizacyjnej

Źródło: Szymańska, 2010, s. 156

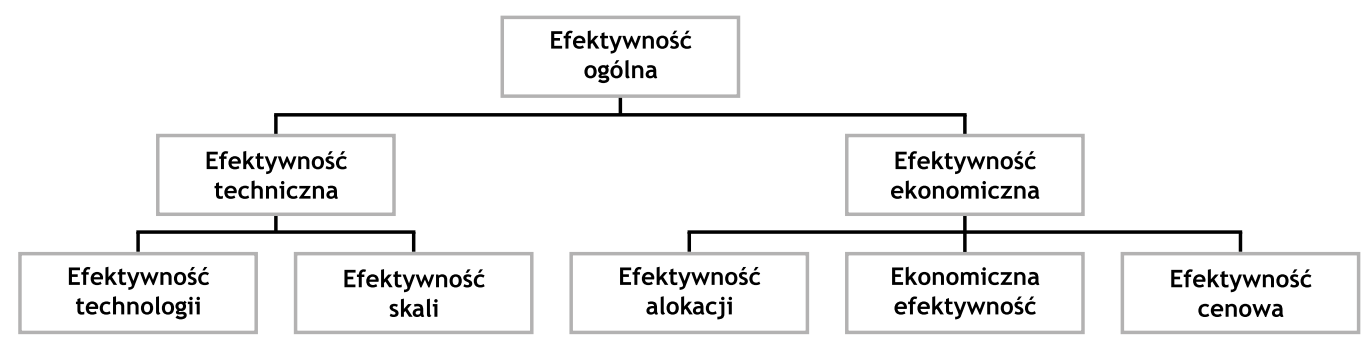

Rys. 2. Klasyfikacja typów efektywności

Źródto: Kowalski, 1992, s. 30 
efektywności e-sklepów znajdują się również: zwrot z inwestycji (ROI), wskaźnik konwersji, wskaźnik porzuceń koszyków, Net Promotor Score (NPS), wskaźnik zaangażowania w social mediach (Engagment Rate), koszt pozyskania klienta (Cost Per Action), liczba reklamacji, średni czas realizacji zamówienia czy liczba błędnych wysyłek. Zwrot z inwestycji mierzony jest jako stosunek zysku netto do całkowitych kosztów. Współczynnik konwersji jest ilorazem liczby transakcji i liczby wizyt. Iloraz liczby porzuconych koszyków i ogólnej liczby koszyków to wskaźnik porzuceń koszyków. Wskaźnik NPS jest różnicą pomiędzy procentem klientów promotorów i destruktorów (klienci promotorzy są gotowi polecić e-sklep swoim znajomym, a klienci destruktorzy są skłonni zniechęcać innych do zakupów). Wskaźnik zaangażowania $\mathrm{w}$ social mediach mierzony jest stosunkiem liczby osób reagujących na publikację posta (przez komentowanie, udostępnianie lub lajkowanie) do zasięgu posta. Stosunek sumy środków wydanych na działania marketingowe do liczby konwersji to wskaźnik CPA (Kich, 2019). Klasyfikację przykładowych wskaźników efektywności w e-commerce i sposób ich pomiaru przedstawia tabela 1 .

Tymczasem G. Bressolles i G. Lang (2019, s. 40) przedstawili propozycje wskaźników efektywności kluczowych dla firm e-commerce, które działają w systemie logistycznym fulfillmentu (tj. przekazujące obsługę logistyczną e-sklepu zewnętrznym operatorom). Są to między innymi: wskaźnik przestarzałych zapasów, procent dostaw na czas, stosunek kosztu transportu do wartości produktu czy średnia stopa zwrotu.
W literaturze widoczna jest mnogość mierników efektywności dla przedsiębiorstwa e-commerce, które pozwalają ocenić skuteczność różnych jego działań. Zastosowanie niektórych $\mathrm{z}$ nich wymaga nieustannego generowania i gromadzenia danych (np. wskaźnik NPS wymusza wysyłanie zapytań do klientów o to, czy poleciliby sklep znajomemu). Wiele wskaźników musi być obliczonych na podstawie wcześniej zebranych danych, np. średnia wartość zamówienia czy wskaźnik porzuceń koszyków (można to zautomatyzować, wykorzystując gotowe skrypty). Niektóre mierniki efektywności można po prostu odczytać ze statystyk witryny sklepu (np. liczbę odwiedzin) lub w serwisach zbierających opinie (np. jakość obsługi).

Ocena działalności sklepów internetowych może być prowadzona zarówno w oparciu o wskaźniki efektywności powszechnie stosowane dla wszystkich przedsiębiorstw handlowych (np. dynamika sprzedaży, przychody, rentowność), jak i inne wskaźniki typowe dla sprzedaży internetowej. Ponadto jakość świadczonych usług przez sklep internetowy może być oceniana przez klientów z wykorzystaniem serwisów zbierających opinie, jak: Trusted Shops, Opineo.pl, Ceneo.pl, Allegro.pl, GetReview.pl czy Facebook. W ten sposób gromadzone są opinie klientów dotyczące: ogólnej działalności e-sklepów, jak też jakości dostawy, jakości towaru, jakości usług serwisowych, szybkości realizacji zamówień, poziomu obsługi klienta, jakości zapakowania przesyłki, gotowości polecenia sklepu znajomym, procentu pozytywnych opinii o sklepie, średniej oceny zakupów, zgodności z opisem, czasu i kosztu wysyłki, średniej oceny firmy i liczby zgromadzonych opinii. Na podstawie liczby pozytywnych i negatywnych

Tabela 1. Klasyfikacja i pomiar wybranych wskaźników efektywności w e-commerce

\begin{tabular}{|c|c|c|}
\hline Rodzaj wskaźników & Nazwa wskaźnika & Sposób pomiaru \\
\hline \multirow{2}{*}{$\begin{array}{l}\text { Wskaźniki } \\
\text { świadomości marki }\end{array}$} & Odwiedziny bezpośrednie & $\begin{array}{l}\text { Liczba użytkowników odwiedzających witrynę sklepu poprzez wpisanie adresu } \\
\text { strony w przeglądarce }\end{array}$ \\
\hline & Wyszukiwania marki w Google & $\begin{array}{l}\text { Liczba użytkowników odwiedzających witrynę sklepu poprzez wpisanie } \\
\text { w wyszukiwarce nazwy/marki sklepu }\end{array}$ \\
\hline \multirow{3}{*}{ Wskaźniki konwersji } & Stopa konwersji & $\begin{array}{l}\text { Stosunek liczby odwiedzających wykonujących określone działanie do liczby } \\
\text { wszystkich odwiedzających witrynę sklepu }\end{array}$ \\
\hline & $\begin{array}{l}\text { Współczynnik konwersji } \\
\text { sprzedaży }\end{array}$ & $\begin{array}{l}\text { Stosunek liczby transakcji sprzedaży do łącznej liczby odwiedzających witrynę } \\
\text { sklepu }\end{array}$ \\
\hline & $\begin{array}{l}\text { Współczynnik konwersji } \\
\text { potencjalnych nabywców }\end{array}$ & $\begin{array}{l}\text { Stosunek liczby potencjalnych nabywców (np. subskrybentów newslettera) do } \\
\text { łącznej liczby odwiedzających }\end{array}$ \\
\hline \multirow{2}{*}{$\begin{array}{l}\text { Wskaźniki utrzymania } \\
\text { klientów }\end{array}$} & Wskaźnik powtórnych zakupów & $\begin{array}{l}\text { Stosunek liczby klientów z co najmniej dwoma zrealizowanymi zamówieniami do } \\
\text { liczby wszystkich klientów, którzy dokonali zakupu }\end{array}$ \\
\hline & Średnia częstotliwość zakupów & Stosunek liczby wszystkich klientów sklepu do liczby zrealizowanych zamówień \\
\hline \multirow{2}{*}{$\begin{array}{l}\text { Wskaźniki jakości } \\
\text { klientów }\end{array}$} & Średnia wartość zamówienia & $\begin{array}{l}\text { Stosunek całkowitej wartości zrealizowanych zamówień do liczby zrealizowanych } \\
\text { zamówień }\end{array}$ \\
\hline & Życiowa wartość klienta & $\begin{array}{l}\text { Iloczyn średniej wartości zamówienia, częstości zakupów i średniej liczby lat } \\
\text { aktywności zakupowej klienta }\end{array}$ \\
\hline Wskaźniki jakości & Ocena biznesu & $\begin{array}{l}\text { Oceny wystawiane przez klienta w systemach zbierających opinie klientów } \\
\text { np. Trusted Shops }\end{array}$ \\
\hline
\end{tabular}

Źródło: opracowanie własne na podstawie: Naik, 2017 
opinii o e-sklepie oraz procentu opinii go rekomendujących oceniano skuteczność sklepów internetowych w badaniach porównawczych sześciu księgarni internetowych (Urban, Buraczyńska, 2017, s. 288-289).

W celu porównania skuteczności działalności kilku przedsiębiorstw $\mathrm{z}$ sektora e-commerce należy tak dobrać mierniki, aby uwzględniały one charakterystyczne dla e-sklepów osiągnięcia. Jednocześnie muszą być one wyznaczalne dla każdego z porównywanych podmiotów, łatwo policzalne i zrozumiałe dla respondentów. Ponadto powinny one odzwierciedlać wiarygodne informacje o funkcjonowaniu przedsiębiorstwa (Choong, 2013, s. 115). Innym problemem w badaniach kwestionariuszowych jest gotowość udzielenia odpowiedzi i przesłania ankiety, stąd też pytania dotyczące wrażliwych danych mogą pozostać bez odpowiedzi.

\section{Metoda badawcza}

C elem prowadzonych pilotażowych badań kwestionariuszowych była ocena efektywności działalności sklepów internetowych z wykorzystaniem celowo dobranych wskaźników i mierników. Do udziału w badaniach zaproszono drogą e-mailową 3146 menedżerów firm prowadzących e-sklepy (wiadomość $\mathrm{z}$ prośbą o udział w badaniach była wysyłana dwukrotnie). Zostały one losowo wybrane z bazy sklepów internetowych Opineo.pl. Kwestionariusz internetowy został wypełniony przez 61 przedsiębiorstw sprzedających produkty z różnych branż, w tym 41 mikroprzedsiębiorstw, 16 małych, 3 średnie i jedno duże przedsiębiorstwo. $\mathrm{W}$ badaniach wzięły udział przedsiębiorstwa $\mathrm{z}$ różną długością stażu w branży e-commerce (od kilku miesięcy do ponad 15 lat), różniące się udziałem wielkości sprzedaży internetowej w sprzedaży ogółem, a także zasięgiem geograficznym - 39 firm działa wyłącznie na terenie Polski, 16 wysyła zamówienia do wybranych krajów europejskich, a 6 obsługuje zamówienia z całego świata. Przeprowadzona analiza przedsiębiorstw objętych badaniem pokazuje ich różnorodność, a tym samym trudność ich porównywania.

Do oceny funkcjonowania sklepów internetowych wybrano takie typowe mierniki (pierwsza część badań), jak:

- liczba unikalnych odwiedzin witryny w miesiącu (liczba unikalnych użytkowników),
- liczba zrealizowanych zamówień w miesiącu,

- procent powracających klientów mierzony stosunkiem liczby zamówień złożonych przez „starych” klientów (takich, którzy dokonywali już wcześniej zakupów w sklepie internetowym) do liczby wszystkich zamówień złożonych w danym miesiącu,

- procent składanych reklamacji mierzony stosunkiem liczby złożonych reklamacji do liczby wszystkich zrealizowanych zamówień $\mathrm{w}$ miesiącu.

W drugiej części badań dokonano oceny biznesu na podstawie opinii klientów gromadzonych $\mathrm{w}$ różnych programach zbierających opinie (druga część badań). Dla każdego ze wskazanych mierników wydzielono 5 interwałów, aby skrócić czas wypełniania kwestionariusza i uzyskać większy zwrot ankiet. Istniała możliwość odmowy odpowiedzi na poszczególne pytania.

W badaniach uwzględniono tylko wybrane KPI, dedykowane dla sektora e-commerce, aby menedżerowie chętniej dzielili się informacjami o osiąganych przez sklep wynikach. Ze względu na takie zawężenie doboru badanych wskaźników efektywności oraz niereprezentatywność badanej próby wyniki badań należy traktować poglądowo.

\section{Wyniki badań kwestionariuszowych}

$\mathrm{U}$ mieszczone w pierwszej części kwestionariusza pytania dotyczące typowych wskaźników efektywności tylko $\mathrm{w}$ dwóch przypadkach pozostały bez odpowiedzi, tzn. zaznaczono odpowiedź „nie wiem/odmawiam odpowiedzi”. Rysunek 1 przedstawia procent respondentów, którzy udzielili odpowiedzi na postawione pytania o średnią miesięczną liczbę odwiedzin przez unikalnych użytkowników, średnią miesięczną liczbę zrealizowanych zamówień, procent klientów powracających (dokonujących ponownych zakupów) i procent składanych reklamacji. Zwrot odpowiedzi na pytania na poziomie $99,2 \%$ świadczy o tym, że respondenci prawdopodobnie znali wartości tych wskaźników efektywności i byli gotowi podzielić się nimi w badaniach.

$\mathrm{Na}$ rysunkach 4-7 przedstawione są zestawienia odpowiedzi udzielanych na poszczególne pytania dotyczące wskaźników efektywności. Widoczne jest zróżnicowanie uzyskiwanych wyników w zakresie średniej miesięcznej

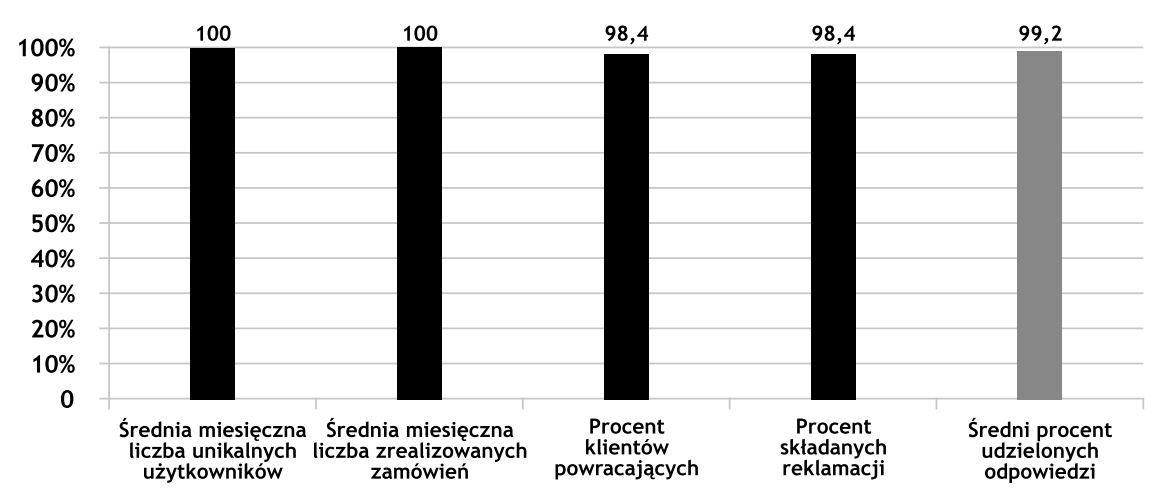

Rys. 3. Procent udzielonych odpowiedzi przez respondentów na pytania dotyczące mierników efektywności

Źródto: opracowanie wtasne 
liczby użytkowników odwiedzających witryny sklepów, średniej liczby zrealizowanych zamówień i procentu klientów powracających. Tymczasem aż 75\% respondentów wskazało, że wskaźnik składanych reklamacji w e-sklepie wynosi poniżej $1 \%$. Stąd też wskazane jest rozważenie zmiany przyjętych interwałów w odpowiedziach tak, aby lepiej uwidocznić różnice pomiędzy badanymi przedsiębiorstwami.

Wybrane mierniki efektywności e-commerce $\mathrm{z}$ powodzeniem mogą służyć porównaniu działań przedsiębiorstw prowadzących sprzedaż internetową. Ich zaletami są wysoka dostępność danych niezbędnych do ich obliczenia oraz niska wrażliwość (menedżerowie chętnie się nimi dzielą). Stąd też należy uznać za zasadne ich wykorzystanie w badaniach kwestionariuszowych przedsiębiorstw e-commerce.

W drugiej części badań kwestionariuszowych respondenci byli pytani o mierniki efektywności tworzone w oparciu o opinie klientów. Rysunek 8 przedstawia zbiorcze zestawienie aktywności przedsiębiorstw prowadzących sklepy

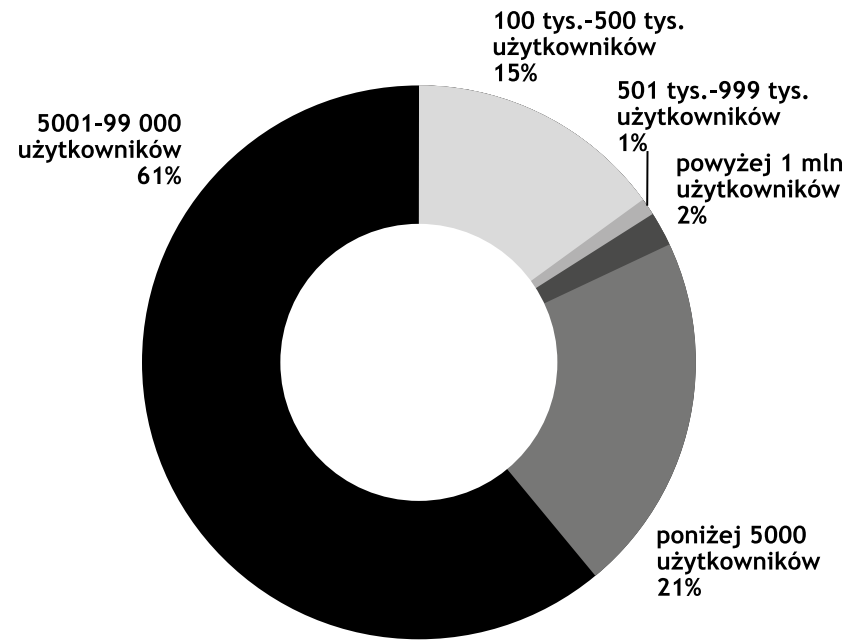

Rys. 4. Średnia miesięczna liczba unikalnych użytkowników odwiedzających witrynę badanych sklepów internetowych Źródto: opracowanie własne

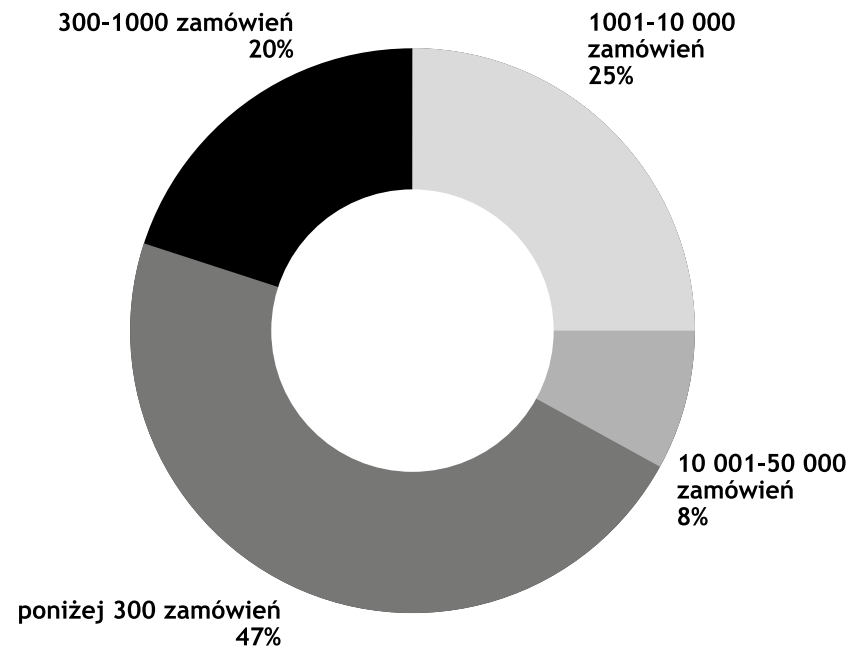

Rys. 5. Średnia miesięczna liczba zrealizowanych zamówień w badanych sklepach internetowych Źródto: opracowanie wtasne internetowe w programach zbierających opinie klientów. Tylko 5\% sklepów internetowych nie interesuje się opiniami klientów na temat swojej działalności. Tymczasem $74 \%$ badanych przedsiębiorstw uczestniczy co najmniej w dwóch programach, a $51 \%$ firm prowadzących e-sklepy gromadzi opinie z wykorzystaniem 3 lub więcej programów.

Rysunek 9 przedstawia popularność różnych programów zbierających opinie klientów wśród badanych sklepów internetowych. Menedżerowie badanych firm najczęściej deklarowali obecność ich sklepów w programach: Allegro (uczestniczy w nim ponad 70\% badanych przedsiębiorstw) oraz program Facebook (67\%). Opinie o sklepach internetowych zbierane są często w serwisach Ceneo. pl (42,6\%) oraz Opineo.pl (prawie 41\%). Tylko nieliczne sklepy uczestniczą w programie zbierania zaufanych opinii o sklepie Trusted Shops (13\%) lub innych programach jak Google (niecałe 10\%) czy Getreview.pl (1,6\%).

Przeprowadzone badania nie wykazały korelacji pomiędzy liczbą programów, w których uczestniczy sklep, a jego wielkością (mierzoną liczbą zatrudnionych pracowników i wielkością obrotów netto). Na aktywność e-sklepu w zakresie przystępowania do programów zbierających opinie o nim nie wpływają również staż w branży, zasięg geograficzny sprzedaży czy udział sprzedaży internetowej przedsiębiorstwa w sprzedaży ogółem.

Wykorzystanie mierników proponowanych przez systemy zbierające opinie klientów pozwala na porównanie działalności tylko tych sklepów internetowych, które uczestniczą w danym programie. Dotychczas nie stworzono miarodajnych sposobów na porównanie przedsiębiorstw, które uzyskały oceny w różnych programach. Wadą zastosowania mierników opartych na opiniach klientów jest ich niedostępność dla znacznej grupy przedsiębiorstw, która waha się od 25\% (dla programu Allegro.pl) do 94\% (dla Google.com). Zaletą wskaźników pozyskiwanych z systemów zbierających opinie klientów jest ich ogólna dostępność - badacz może samodzielnie odczytać wyniki (lub sprawdzić poprawność wyników

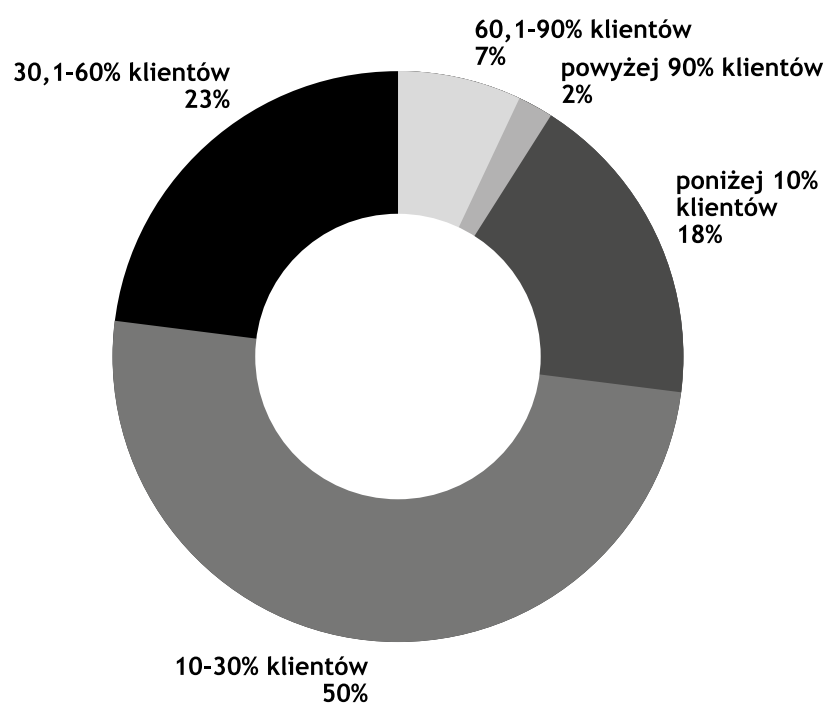

Rys. 6. Procent klientów powracających (dokonujących ponownych zakupów w sklepie internetowym)

Źródto: opracowanie wtasne 


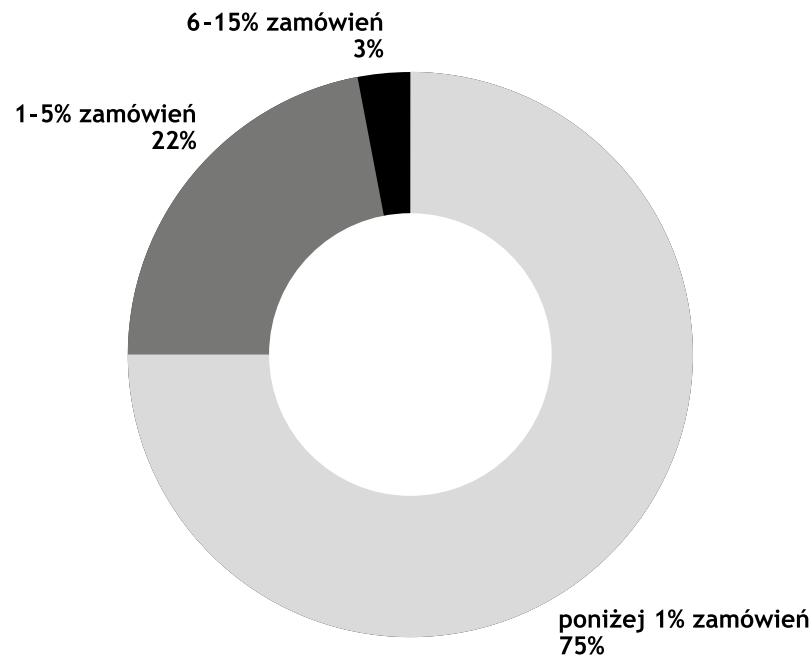

Rys. 7. Procent składanych reklamacji w badanych sklepach internetowych

Źródto: opracowanie własne

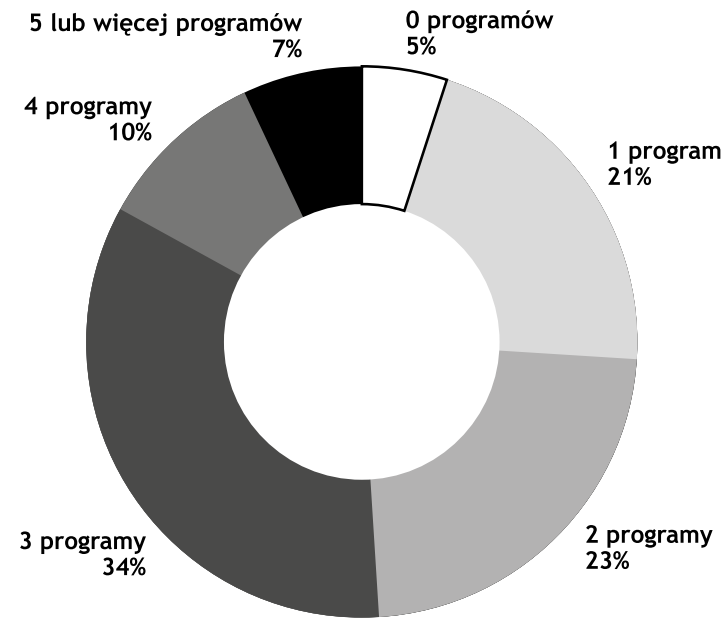

Rys. 8. Uczestnictwo sklepów internetowych $w$ programach zbierających opinie klientów (tj. w programach: Allegro.pl, Facebook, Ceneo.pl, Trusted Shops, Google, Getreview i in.) Źródto: opracowanie własne

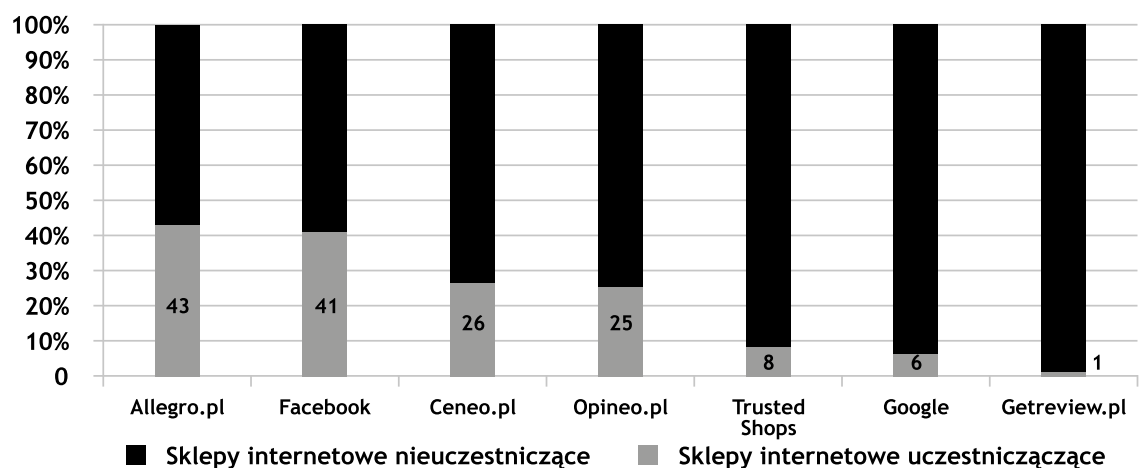

Rys. 9. Popularność różnych programów zbierających opinie klientów wśród badanych sklepów internetowych

Źródło: opracowanie własne

zadeklarowanych przez respondenta). Stąd też przy celowym doborze respondentów można dokonać porównania skuteczności sklepów internetowych bez angażowania menedżerów przedsiębiorstw.

Chociaż mierniki efektywności oparte na ocenie klientów zgromadzone w systemach zbierających opinie można stosunkowo łatwo pozyskać od respondentów, to nie zawsze jest uzasadnione ich wykorzystanie (np. w badaniach organizacji nieuczestniczących w żadnych programach gromadzących opinie albo $\mathrm{w}$ badaniach przedsiębiorstw zbierających opinie klientów w innych programach). Tymczasem przy celowym doborze próby uwzględniającym uczestnictwo przedsiębiorstw w określonych programach zbierających opinie klientów wykorzystanie zaproponowanych mierników efektywności należy uznać za zasadne.

\section{Podsumowanie}

$\mathrm{P}$ ilotażowe badania kwestionariuszowe pokazały zasadność wykorzystania zaproponowanych wskaźników efektywności w ocenie przedsiębiorstw e-commerce $\mathrm{z}$ wykorzystaniem kwestionariusza ankietowego (pierwsza część badań). Dobór wskaźników efektywności dla przedsiębiorstw e-commerce należy uznać za słuszny. Na procent udzielonych odpowiedzi pozytywny wpływ miał nie tylko odpowiedni dobór wskaźników, ale również zastosowanie pięciostopniowej skali (5 interwałów). W analizie porównawczej przedsiębiorstw widoczność różnic zależy od właściwego doboru interwałów odpowiedzi.

Opinie klientów stanowią bogate źródło mierników efektywności, ale wykorzystywanie przez sklepy internetowe różnorodnych systemów gromadzenia opinii (zbierających oceny różnych aspektów funkcjonowania, w różnych skalach i na różnych zasadach) utrudnia porównanie ich wyników. Stąd też przy zastosowaniu tej grupy mierników wskazane jest opracowanie algorytmu przeliczania mierników efektywności pochodzących z różnych systemów zbierających opinie klientów. Mierniki te mogą być też stosowane przy celowym doborze respondentów (tj. $\mathrm{w}$ badaniach firm zbierających opinie klientów w tym samym programie). Dodatkową zaletą mierników efektywności opartych na opiniach klientów jest bezpośredni dostęp badacza do danych źródłowych. Wykorzystanie pozaekonomicznych mierników efektywności opierających się na opiniach klientów wymaga 
nieustannego śledzenia trendów dotyczących wykorzystania programów zbierających opinie przez właścicieli sklepów internetowych.

Chociaż pozyskane dane i wyniki nie są reprezentatywne, to stanowią one dobrą podstawę do prowadzenia dalszych badań i uzyskania oryginalnych rozwiązań. Problematyka pomiaru efektywności przedsiębiorstw e-commerce jest tematem bardzo aktualnym. Planowane jest przeprowadzenie badań właściwych na reprezentatywnej grupie przedsiębiorstw, jednakże wskazana jest wcześniejsza korekta kwestionariusza, aby interwały lepiej odpowiadały faktycznym rozkładom badanych cech. Stąd też celowe byłoby przeskalowanie odpowiedzi tych pytań, w których ponad $40 \%$ badanych wybrało tę samą opcję. Ograniczeniem przeprowadzonych badań było uwzględnienie tylko nielicznej grupy mierników/wskaźników efektywności. Dlatego w dalszych badaniach należy rozważyć rozszerzenie kwestionariusza o dodatkowe pytania dotyczące innych wskaźników.

\section{mgr inż. Barbara Buraczyńska \\ Politechnika Lubelska \\ Wydział Podstaw Techniki \\ ORCID: 0000-0002-9999-8231 \\ e-mail: b.buraczynska@pollub.pl}

\section{Bibliografia}

[1] Bressolles G., Lang G. (2019), KPIs for Performance Measurement of e-fulfillment Systems in Multi-channel Retailing, „International Journal of Retail \& Distribution Management", Vol. 48, No. 1, pp. 35-52.

[2] Choong K.K. (2013), Understanding the Features of Performance Measurement System: A Literature Review, „Measuring Business Excellence”, Vol. 17, No. 4, pp. 102-121.

[3] Głodziński E. (2015), Efektywność w naukach o zarządzaniu. Przyczyny wieloznaczności i rekomendacje dotyczace ich ograniczenia, „Zeszyty Naukowe Politechniki Śląskiej, Seria: Organizacja i Zarządzanie", Nr 83, s. 165-176.

[4] Holstein-Beck M. (1997), Być albo nie być menedżerem, Indor Book, Warszawa.

[5] Jaki A. (2011), Paradygmat efektywności w zarzadzaniu, „Przegląd Organizacji”, Nr 4, s. 3-7.

[6] Kaden R.J. (2008), Badania marketingowe, Wyd. Naukowe PWN, Warszawa.

[7] Kich M. (2019), Jakie KPI mierzyć w e-Commerce? https://x-coding.pl/blog/ecommerce/jakie-kpi-mierzyc-w-ecommerce/, data dostępu: 28.12.2019 r.

[8] Kowalski Z. (1992), Kategorie efektywności produkcji ( $w$ świetle teorii funkcji produkcji), ,ZER”, Nr 4, s. 18-31.

[9] Naik P. (2017), 10+E-commerce KPIs that Your Business Needs to Track Immediately, https://business.trustedshops.co.uk/blog/10-kpis, access date: 28.12.2019.

[10] Osbert-Pociecha G. (2007), Relacja między efektywnością i elastycznością organizacji, [w:] T. Dudycz, Ł. Tomaszewicz (red.), Efektywność - rozważania nad istota i pomiarem, Wyd. Akademii Ekonomicznej we Wrocławiu, Wrocław, s. 337-349.
[11] Parmenter D. (2015), Key Performance Indicators: Developing, Implementing, and Using Winning KPIs. John Wiley \& Sons.

[12] Saniuk A., Saniuk S. (2017), Strategiczne zarzadzanie wynikami $w$ przedsiębiorstwach realizujących produkcję na zamówienie, „Zeszyty Naukowe Politechniki Śląskiej. Seria: Organizacja i Zarządzanie", Nr 103, s. 207-216.

[13] Skawińska E., Zalewski R.I. (2016), Konkurencyjność - kluczowe czynniki sukcesu przedsiębiorstw XXI w., „Przegląd Organizacji”, Nr 3, s. 16-25.

[14] Skrzypek E. (2012), Efektywność ekonomiczna jako ważny czynnik sukcesu organizacji, [w:] T. Dudycz, G. Osbert-Pociecha, B. Brycz (red.), Efektywność - konceptualizacja i uwarunkowania, „Prace Naukowe Uniwersytetu Ekonomicznego we Wrocławiu”, Nr 262, s. 313-325.

[15] Słownik ekonomiczny przedsiębiorcy (2000), red. Z. Dowgiałło, Wyd. Znicz, Szczecin.

[16] Szymańska E. (2010), Efektywność przedsiębiorstw - definiowanie i pomiar, „Roczniki Nauk Rolniczych” Seria G, T. 97, z. 2, s. 152-164.

[17] Urban W., Buraczyńska B. (2017), E-commerce Flexibility Studied on the Basis What Can be Obtained from the Customer Interface, [in:] M. Przygoda, M. Cingula, L. Yongqiang (eds.), International Scientific Conference on Economic and Social Development - „Managerial Issues in Modern Business”. Book of Proceedings, Varazdin Development and Entrepreneurship Agency, Warszawa, s. 283-291.

[18] Zagajewski A., Saniuk S. (2018), Kluczowe wskaźniki efektywności w e-commerce, „Zeszyty Naukowe Politechniki Śląskiej. Seria: Organizacja i Zarządzanie", Nr 118, s. 691-701.

[19] Zawadzki S. (2018), Kluczowe wskaźniki efektywności dla e-commerce, https://smartbees.pl/blog/kluczowe-wskazniki-efektywnosci-dla-e-commerce, data dostępu: 28.12.2019 r.

[20] Ziębicki B. (2014), Efektywność organizacyjna podmiotów sektora publicznego, „Zeszyty Naukowe Uniwersytetu Ekonomicznego w Krakowie. Seria specjalna: Monografie”, Nr 234.

\section{Efficiency Measurement of e-commerce Sector Enterprises in Questionnaire Surveys}

\section{Summary}

Efficiency is an ambiguous concept, defined in a variety of ways. The article presents the issue of measuring the efficiency of enterprises operating online stores. The author presents performance indicators typical of companies selling via the Internet. Then, those that were used to assess the effectiveness of e-commerce enterprises in questionnaire surveys were selected. The research results were subjected to analysis and discussion, which considered the specificity of companies running online stores. The questionnaire studies demonstrated the advantages and disadvantages of using selected indicators to measure efficiency.

\section{Keywords}

e-commerce, KPI, online stores, questionnaire surveys, efficiency 